\title{
Urban freight characteristics and externalities - A comparative study of Gothenburg (Sweden) and Delhi (India)
}

\begin{tabular}{|c|c|}
\hline $\begin{array}{l}\text { Authors: } \\
\text { Saubhagya Di } \\
\text { K. Ramachanc } \\
\text { Geetam Tiwa } \\
\text { Sönke von Wi }\end{array}$ & $\begin{array}{l}\text { xit }^{1} \text { (1) } \\
\operatorname{lra}^{2} \operatorname{Rao}^{2} \\
\mathrm{i}^{2} \text { (1) } \\
\text { eding }\end{array}$ \\
\hline $\begin{array}{l}\text { Affiliations: } \\
{ }^{1} \text { Scientist Cen } \\
\text { Control Board }\end{array}$ & $\begin{array}{l}\text { tral Pollution } \\
\text {, Delhi, India }\end{array}$ \\
\hline $\begin{array}{l}{ }^{2} \text { Department } \\
\text { Engineering a } \\
\text { Transportatio } \\
\text { and Injury Pre } \\
\text { Centre, Indiar } \\
\text { Technology, D }\end{array}$ & $\begin{array}{l}\text { of Civil } \\
\text { nd } \\
\text { Research } \\
\text { vention } \\
\text { Institute of } \\
\text { elhi, India }\end{array}$ \\
\hline $\begin{array}{l}{ }^{3} \text { Project Man } \\
\text { Your Maritim } \\
\text { Partner, Goth }\end{array}$ & $\begin{array}{l}\text { ger at SSPA, } \\
\text { Solution } \\
\text { enburg, Sweden }\end{array}$ \\
\hline $\begin{array}{l}\text { Correspondin } \\
\text { K. Ramachanc } \\
\text { rrkalaga@civi }\end{array}$ & $\begin{array}{l}\text { g author: } \\
\text { Ira Rao, } \\
\text { liitd.ac.in }\end{array}$ \\
\hline $\begin{array}{l}\text { Dates: } \\
\text { Received: } 22 . \\
\text { Accepted: } 27 \\
\text { Published: } 25\end{array}$ & $\begin{array}{l}\text { une } 2021 \\
\text { Sept. } 2021 \\
\text { Feb. } 2022\end{array}$ \\
\hline $\begin{array}{l}\text { How to cite tI } \\
\text { Dixit, S., Rao, } \\
\text { \& Von Wiedin } \\
\text { 'Urban freigh } \\
\text { and externalit } \\
\text { comparative s } \\
\text { Gothenburg ( } \\
\text { Delhi (India)', } \\
\text { Transport anc } \\
\text { Management } \\
\text { https://doi.or } \\
\text { jtscm.v16i0.6 }\end{array}$ & $\begin{array}{l}\text { is article: } \\
\text { K.R., Tiwari, G. } \\
\text { g, S., 2022, } \\
\text { characteristics } \\
\text { ies - A } \\
\text { tudy of } \\
\text { Sweden) and } \\
\text { Journal of } \\
\text { Supply Chain } \\
\text { 16(0), a629. } \\
\text { g/10.4102/ } \\
29\end{array}$ \\
\hline $\begin{array}{l}\text { Copyright: } \\
\text { (c) 2022. The } \\
\text { Licensee: AOS } \\
\text { is licensed un } \\
\text { Creative Com } \\
\text { Attribution Li }\end{array}$ & $\begin{array}{l}\text { Authors. } \\
\text { IS. This work } \\
\text { der the } \\
\text { mons } \\
\text { ense. }\end{array}$ \\
\hline Read online: & \\
\hline 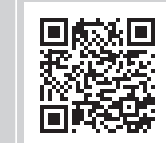 & $\begin{array}{l}\text { Scan this QR } \\
\text { code with your } \\
\text { smart phone or } \\
\text { mobile device } \\
\text { to read online. }\end{array}$ \\
\hline
\end{tabular}

Authors:

Saubhagya Dixit ${ }^{1}$

Geetam Tiwari² (D)

Sönke von Wieding ${ }^{3}$

${ }^{1}$ Scientist Central Pollution

${ }^{2}$ Department of Civi

Engineering and

Transportation Research

Centre, Indian Institute of

Technology, Delhi, India

${ }^{3}$ Project Manager at SSPA Your Maritime Solution

Corresponding author:

K. Ramachandra Rao,

Dates:

Accepted: 27 Sept. 2021

How to cite this article:

xit, S., Rao, K.R., Tiwari,

'Urban freight characteristics

and externalities - A

Gothenburg (Sweden) and

jtscm.v16i0.629

Copyright:

2022. The Authors.

Licensee: AOSIS. This work

is licensed under the

Creative Commons

Attribution License.
Background: The urban freight transportation (UFT) system is an essential facilitator for the smooth functioning of city logistics. It also contributes significantly to transportation-related issues, such as vehicular congestion, pollution, accidents, infrastructure damage and other related problems.

Objectives: This study aimed to understand and compare the urban freight traffic characteristics and their impact in two cities: Gothenburg, Sweden and Delhi, India, having high socio-economic differences. The findings of this study will be helpful for practitioners and policymakers in the development and successful implementation of UFT management policies.

Method: Using the cordon count (traffic data), retailers' interviews (receivers' data) and freight vehicle drivers' interviews, UFT characteristics such as sector-specific contribution, trip characteristics, vehicular characteristics and negative impacts in terms of external cost to society are evaluated. This study also discusses the prediction of attracted trips in the study zone using freight trip attraction (models.

Results: About $75 \%$ of the trips in Gothenburg and $92 \%$ of the trips in Delhi are made by light commercial and other small-sized vehicles. Gothenburg has formally organised sectors involved in freight vehicle movement; however, Delhi has informally organised sectors.

Conclusion: The results revealed substantial differences in characteristics of freight trip operations in both the cities, compared with few similarities. Measures taken considering the specific local attributes of freight traffic and stakeholders' requirement may lead to a sustainable transportation system in cities.

Keywords: urban freight transportation; external cost; freight trip attraction; non-motorised vehicle; marginal external cost; vehicular emissions.

\section{Introduction and background}

Cities have been growing at a rapid rate since the past few decades, and so has their need for transporting goods and people. According to the United Nation's forecast, by the end of 2050, around $68 \%$ of the world's population will be the urban population and the rate of urbanisation will be much faster in developing countries, such as India and China (UN DESA 2019). The movement of goods in any city, that is, urban freight transportation (UFT), plays a vital role in the city's economy and lifestyle, whether it is a supply of goods or collection of waste. The European Commission defines UFT as the movement of the freight vehicles whose primary purpose is to carry goods into, out of and within urban areas (Transmodal 2012). The majority of the freight vehicle trips in urban areas are because of commercial activities (Holguín-Veras \& Jaller 2014). The pressure of population growth in urban areas has resulted in the spread of city boundaries and logistics sprawl, that is, spatial de-concentration of logistics facilities and distribution centres in the metropolitan regions (Dablanc 2011), which are responsible for more and longer freight vehicle trips.

The share of freight vehicles in city traffic is generally low. However, because of different physical and dynamic characteristics (like slow acceleration and sheer size) as well as operational behaviour (like consumer-oriented delivery time, multiple stops, etc.), their contribution towards negative impacts (congestion, air and noise pollution, accidents, climate change and infrastructure damage) is significant (Browne et al., 2007, 2012; Dablanc 2007; Ewbank et al. 2020; Goel \& Guttikunda 
2015; Ogden 1992; Taniguchi \& Thompson 2018; Transmodal 2012). These impacts result from interactions amongst goods, facilities, infrastructure and vehicles in four subsystems accessibility, land use, transport and traffic integration (Lindholm 2012). Some of the impacts of urban freight are limited to the area where the vehicle movement takes place, and these effects last for a short duration of time, for example, noise pollution, congestion-related problems, infrastructure damage, etc., whilst other impacts are not bounded, and they affect a larger area over a long period like environmental emission and climate change (Behrends 2011; Behrends, Lindholm \& Woxenius 2008). The scale of local impact is proportional to the population density in that locality (Maibach et al. 2007). Freight traffic represents around 20\%$30 \%$ of vehicle kilometres travel and $16 \%-50 \%$ (depending on the pollutant considered) of the emission of air pollutants by transport activities in a city (LET-Aria Technologies 2006). In developing countries like India, urban freight vehicle travel of total metropolitan vehicle travel is substantial with 37\% contribution (Punte, Gota \& Peng 2013).

The classic focus on city planning does not include goods (Sjöstedt 2007) and most of the facilities or infrastructure in cities are developed, considering the requirements of the passenger transportation system. There is a strong need for coordination between passenger and freight transportation planning (Anderson, Allen \& Browne 2005; Lindholm 2012; Taniguchi \& Thompson 2018). Increasing attention towards UFT in the past few decades is because of growing awareness and concern about the environmental impact of transport and the implications for the economic vitality of cities caused by congestion problems (Lindholm \& Behrends 2012). In order to improve the logistics performance and reduce the negative environmental or socio-economic impacts, various urban freight transport measures have been introduced in different cities across the globe, such as off-peak hour deliveries, urban consolidation centres, dedicated transhipment areas and loading or unloading zones, low emission zones, deliveries by electric vehicles and many more (De Oliveira et al. 2021; Karakikes \& Nathanail 2020; Transmodal 2012; Taniguchi \& Thompson 2018). The results, however, are disappointing, showing unwanted side effects or dependency on government subsidies, which is mainly because the measures were planned without taking into account the unique characterisation of the city and traffic, as well as the interests of all concerned stakeholders (Amaya, Arellana \& Delgado-Lindeman 2020; Macharis \& Melo 2011; Transmodal 2012). Therefore, a prerequisite for the successful implementation of urban logistics measures requires a good knowledge about the framework conditions of the particular context. A systematic approach for understanding the present city logistics scenario and then searching for the scope of improvement will help achieve the goal of sustainable urban freight transportation (SUFT).

Transferability to facilitate the application of sustainability measures has limitations because of a lack of data and literature. Therefore, there is a need for empirical research of specific megacities (Kin, Verlinde \& Macharis 2017).
Successful sustainable freight measure requires a regular and detailed study of traffic, including heavy commercial vehicles and business establishments (Oskarbski \& Kaszubowski 2018). This study tries to understand the urban freight traffic characteristics in two cities and analyses their similarities and differences. Two cities, Gothenburg (Sweden) and Delhi (India), having significant socio-economic differences were selected to answer the following research questions:

1. Does the UFT system have similar characteristics in developed (Sweden) and developing (India) nations and how much are these systems generating negative impact?

2. Which are the sectors involved in urban freight and how much is their relative contribution to total freight traffic?

3. What are the variables used to estimate the freight trips attraction in commercial land use?

This study focuses on characteristics of UFT (sector-specific contribution, trip characteristics, vehicular characteristics, freight delivery patterns, etc.) and also quantifies the negative impacts in terms of external cost (congestion, emissions, accidents, noise, climate change and infrastructure damage.), that is, cost borne by the society and not by the transport user (Sen, Tiwari \& Upadhyay 2010). The study also tries to explain the relative contribution and performance of different sectors in urban freight traffic. The freight trip attraction (FTA) models are also developed, which can help in the estimation of total freight trips. Furthermore, it provides an overview of urban freight traffic characteristics of two different cities. The study findings will also be helpful for practitioners and policymakers to understand urban freight characteristics and associated problems, which will assist them in selecting appropriate sustainable urban freight measures for their city.

This study is organised as follows: Section 'Case description' provides the description of the cases; Section 'Research approach' discusses the research approach of data collection, data processing and data analysis; Section 'Findings of the study' deliberates on findings of the study focusing on the characteristics of freight traffic in the study zones; Section 'Freight delivery patterns (based on receivers' data)' discusses freight delivery patterns and FTA models; Section 'Externalities due to urban freight traffic in study zones' deals with externality because of freight traffic in study zones, and Section 'Conclusion' presents conclusions.

\section{Case description}

Two commercial activity zones located in Gothenburg (Sweden) and Delhi (India) were selected for this study. Gothenburg is the second-largest city in Sweden, with around 0.58 million (2020) and spread over $450 \mathrm{~km}^{2}$ area (Statistics Sweden 2020). Most of the commercial activities in Gothenburg are concentrated in the city centre area. In comparison, Delhi is India's capital city, spread over 1500 $\mathrm{km}^{2}$, with an estimated urban population of 19.3 million (Census 2011 2020). Delhi is a central distribution hub, where more than half of the freight imported is again re-exported. The central part of the city, Old Delhi, is very congested, 
which is a hub for wholesale and retail businesses. Commercial areas in Delhi are not concentrated, and they are spread all over the city. The major shopping districts in Delhi include Connaught Place, Chandni Chowk, Nehru Place, Sarojini Nagar and many other shopping malls in the city.

The first study zone (service area: $90000 \mathrm{~m}^{2}$ ) is in Inom Vallgraven, inside the city centre of Gothenburg, Sweden. The study zone has a high number of retail stores, restaurants, hairdressers, supermarkets and offices, where business functions can occupy up to $95 \%$ of the area (Kaczorowska 2014). The study area covers eight entrance and exit streets and four loading bays. Site map of the study zone at the city centre of Gothenburg is shown in Figure 1a.

The area selected for the case study in Delhi is Sarojini Nagar Market (service area: $60000 \mathrm{~m}^{2}$ ). It is a famous shopping attraction centre in Delhi, which witnesses thousands of daily footfalls, especially for clothes shopping. The market area consists of approximately 500 stores of clothes, footwear, electronics, furniture, restaurants, food outlets and groceries. Narrow streets and heavy pedestrian movement are some of the unique features of this market area. Figure $1 b$ shows the site map of the study zone in Delhi.

\section{Research approach}

Urban freight transportation is an emerging field of study where the 'case research' approach will be helpful to understand the characteristics and effects (Meredith 1998; Voss, Tsikriktsis \& Frohlich 2012). The case study uses a data triangulation approach (use of multiple sources and methods), which improves the validity and reliability of case study findings. McCutcheon et al. (1993) have also mentioned that data collection may be in the form of personal observations, structured and unstructured interviews, review of previously collected data, status reports, etc. This study uses cordon counts (traffic data), retailers' interviews (receivers' data) and freight vehicle drivers' interviews.

For traffic data, a secondary data source compiled by DB Schenker under the Send Smart Project during 18 and 19 December 2013 from 6:30 to 18:00 was used for the study zone in Gothenburg. However, traffic data for Sarojini Nagar market, Delhi, were collected on 21 August 2014 from 6:30 to 16:00 and 21:00 to 22:30 (vehicle entry restriction from 16:00 to 21:00). The vehicle registration plate number, time and place of entry or exit, company name and type of vehicle were recorded on each entry or exit point. The data were further processed using the available public databases, wherein vehicle-related attributes, such as vehicle ownership, gross vehicle weight, environmental class and fuel type, and the associated sector (public database for associated sectors is only available for Gothenburg), were identified (Delhi Vahan Sewa 2015; Transport Styrelesn 2014; UC All Companies Ltd. 2014). The traffic data were converted into trips using the following assumptions: (1) considering the multiple serving locations in the study or /nearby area, multiple entry or exit by the vehicle having a licence plate within the duration of 30 min was counted as a trip; (2) vehicles with a travel time less than 2 min were considered as through traffic and are not counted as destined trips; and (3) in the case of non-motorised vehicles, which do not have a licence plate (challenging to differentiate vehicles), single entry-exit of a vehicle is counted

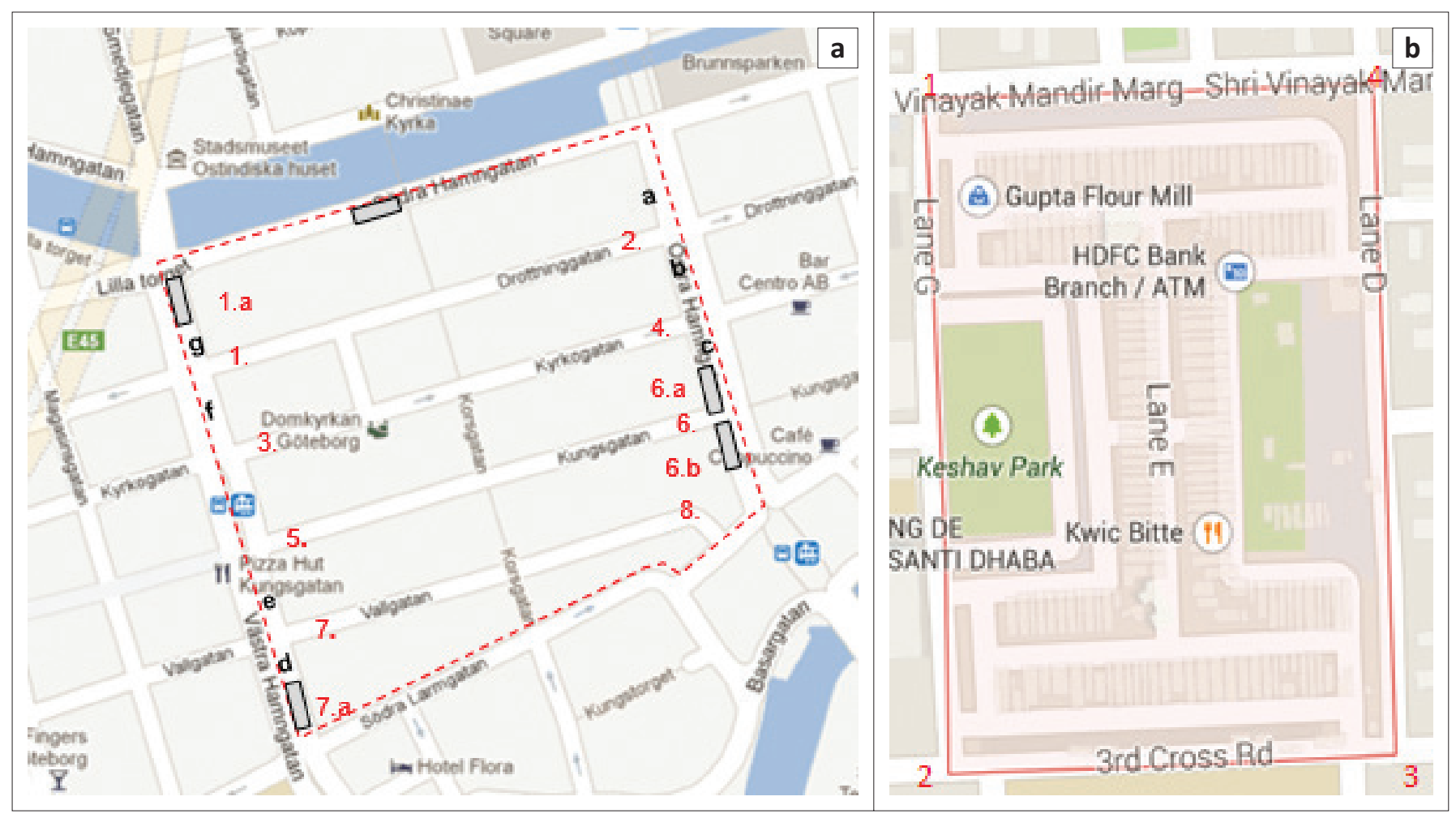

Source: Google Maps, 2015, Map of Inom Vallgraven, Sweden and Sarojini Nagar Market, Delhi, India, viewed 11 January 2020, from https://www.google.com/maps/. FIGURE 1: Map (a-b) map of study zones at Gothenburg and Delhi. 
as a trip. Correction factors of 0.78 and 0.66 were applied for Gothenburg and Delhi, respectively, for unidentified trips, because of errors in data recording.

Furthermore, to understand the freight delivery pattern and to develop FTA models, personal interviews were conducted for 50 stores in Gothenburg and 102 stores in Delhi using a customised survey format (Holguin-Veras et al. 2012). During the survey, information regarding the type of activity, freight delivery characteristics such as type of vehicle, frequency of delivery and cargo weight, were also recorded. In the case of Delhi, retailers' data were also supplemented by 68 drivers' interviews, having the focus on trip origin destination, frequency of visit to the study area, type of visitor: regular or occasional, load factor (carried weight divided by permissible weight), number of stores served in a trip, nearby places served in a trip and the like.

\section{Findings of the study}

This section discusses freight traffic's general characteristics, such as freight trips and their distribution over time, share of different sectors in freight traffic, types of vehicles used and associated environmental emissions.

\section{Characteristics of freight vehicle trips}

The variation of freight trips over time for study zones in Gothenburg (average of 2-day data) and Delhi is discussed, as shown in Figure 2. Both the study zones have two peaks, a morning peak higher than the afternoon peak. Most of the freight activities in Gothenburg were performed before and during the morning peak time (before 11:00). However, in the case of Delhi, during morning time (07:00 to 09:00), freight traffic was low and freight activities were distributed throughout the day. In Gothenburg, the morning peak lies between 09:00 and 11:00, and the afternoon peak between 12:30 and 14:30. The position of the peak for freight traffic in Delhi is shifted towards the right of Gothenburg, where the morning peak is between 10:00 and 12:00 and the afternoon peak lies just before starting of vehicle entry restriction, that is, $15: 00$ to $16: 00$. Around $8 \%-10 \%$ of daily freight traffic is

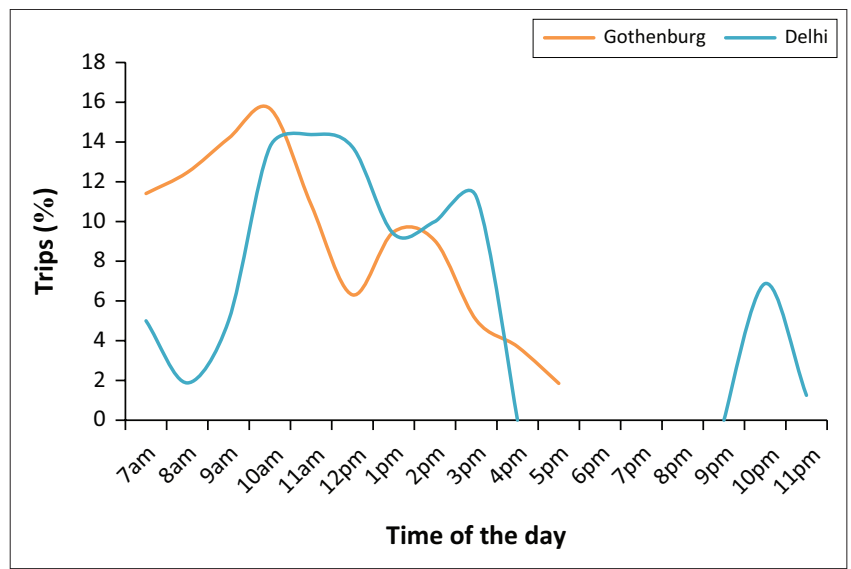

FIGURE 2: Variation of freight trips over time of the day. observed after the end of vehicle entry restriction in Sarojini Nagar market.

Every freight vehicle in Gothenburg was associated with a particular sector (Statistics Sweden 2014). In order to have a better understanding, these sectors were classified under seven broad categories: (1) third party logistic provider (3PLP), (2) construction and maintenance, (3) express courier and post, (4) hotel Restaurant and catering (HoReCa), (5) retail, (6) service and (7) waste collection. However, the majority of vehicles in Delhi do not have any formal association with a specific sector.

It was found from the analysis of data that the freight traffic in the city centre of Gothenburg was diverse. No single sector had a dominating share. The largest sector was 3PLP, which was responsible for about one-fourth of freight traffic. The analysis also shows that two-thirds of the medium and heavy vehicle trips in the city centre area were because of 3PLP and waste collection sectors. Similar observations were made for the waste collection sector in Delhi. The HoReCa sector contributed 16.5\% to freight trips by heavy vehicles. Share of other sectors was significantly less and varied between $2.4 \%$ and $5.9 \%$. The contribution of different sectors in total freight traffic, their share in Heavy Commercial Vehicle (HCV) trips and share in the use of loading or unloading bays are discussed, as shown in Figure 3. Although in the case of Delhi, most of the freight vehicles are not formally registered or associated with a particular sector, almost three-fourth of the drivers are commuters, which indicates the presence of informally organised sectors.

It is also observed that waste collection operations are made in the morning hours only, up to 11:30 in Gothenburg. The peak of freight traffic for the retail and HoReCa sector is between 9:30 and 13:30. The share of 3PLP sector is spread throughout the day; however, its peak coincides with the overall peak of freight traffic.

Vehicle utilisation for freight vehicle operations in Gothenburg in terms of the number of vehicle trips per day for different sectors was calculated. It was observed that the

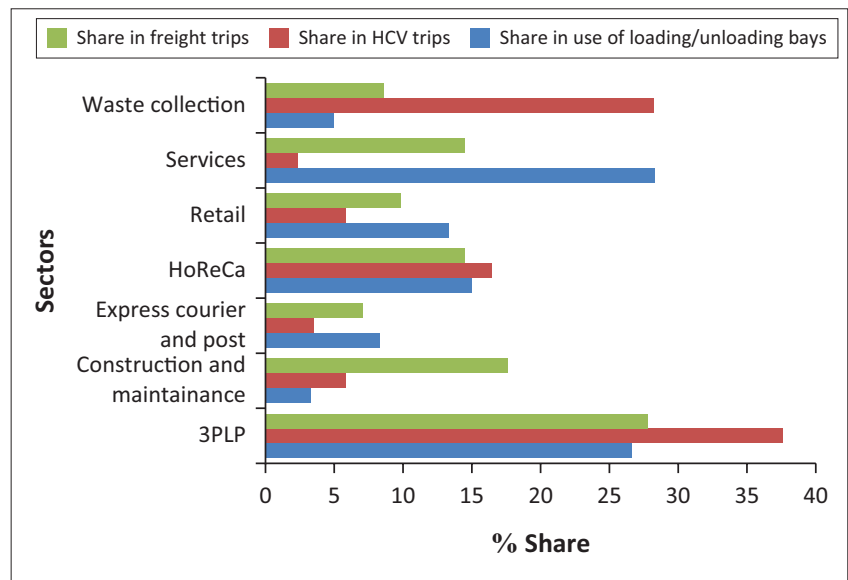

FIGURE 3: The share of different sectors in freight traffic in the study zone at Gothenburg, Sweden. 
sector with the largest freight vehicle fleet and freight trip share, the 3PLP, has the highest vehicle utilisation ratio (trips per vehicle per day) of 1.70 . Other sectors, namely, waste collection, construction and maintenance, HoReCa, service, retail and the express courier, have the vehicle utilisation ratios of $1.47,1.39,1.38,1.27,1.19$ and 1.10 , respectively.

The trip duration-frequency plot for freight vehicle trips in both the study zones follows a log-normal distribution, having a median of 14 and $19 \mathrm{~min}$ for Gothenburg and Delhi, respectively. It is also observed that the median for the waste collection sector (28 $\mathrm{min}$ ) is highest amongst all the sectors because waste collection trucks have multiple stoppages, and they are required to cover a larger area.

There were four loading bays present in the study zone at Gothenburg, which could be used by any freight vehicle for loading and unloading operations. Figure 3 shows the share of different sectors using loading or unloading bays. It was observed that vehicles from the service sector, having a share of $14.5 \%$ trips, were using the loading bay facility the most with its share of around $28.3 \%$. This may be an indication that service vans are using loading bays for parking. The 3PLP sector is the second largest sector with a share of $26.7 \%$. Other sectors have much less share in utilisation of loading bays: construction and maintenance $(3.3 \%)$, express courier and post $(8.3 \%)$, HoReCa $(15 \%)$, retail $(13.3 \%)$ and waste collection (5\%). There is no such dedicated parking area or loading bays for freight vehicles in Sarojini Nagar market. Either delivery is made directly in front of the shops during off-peak time or vehicle is parked in a common parking area with passenger vehicles and cargo is carried to the shop. During peak hours of shopping, there is hardly any place available for freight vehicles to park.

\section{Modal split}

It is observed that for the study zone in Gothenburg, 74\% of trips were made by light commercial vehicles (LCVs $<3.5$ tons) and $26 \%$ trips by heavy commercial vehicles (> 3.5 tons). However, a variety of vehicles were used for freight operations in the study area in Delhi, having the maximum share $(34 \%)$ of mini-light commercial vehicle (mini-LCVs $<1.5$ tons). A significant number of trips (28\%) were operated on passenger transport vehicles, such as autorickshaws $(14 \%)$, cycles $(5 \%)$ and two-wheelers $(9 \%)$. The rest of the trips were made by delivery vans (3\%), LCVs $(5 \%)$, heavy commercial vehicles (8\%) and cycle rickshaw trolley (CRT) (22\%). Delivery vans include both personal cars and commercial vans. It may be noted that the share of nonmotorised transport (cycles and CRT) is almost 27\%. The higher share of CRT is because of not only delivery trips but also other freight activities like waste collection, transferring goods from the parking area to shops, home delivery of furniture and electronic items, etc. Autorickshaws are used to get cargo to the market area mainly by unauthorised shops and by authorised shops in case of urgent demand. The use of autorickshaws for freight movement is in practice because of easy availability and comparatively lower cost of transportation. The results of the study were also validated by the findings of the study of other researchers. Gupta (2017) mentioned that LCVs, trucks and autorickshaws form the backbone of urban goods movement in Delhi for longer distances. For short distances, non-motorised vehicles (e.g. animal cart, hand cart, head load, cycle rickshaw) are extensively used, especially in highly congested parts of Delhi. Another interesting fact is that with an increase in online shopping, companies are using motorised two wheelers as an option to navigate the high density and congestion of Delhi (Nilanjana et al 2017).

Analysis of data collected through drivers' interviews in Sarojini Nagar market also suggests that around $74 \%$ of drivers were commuters to the Sarojini Nagar market. The LCVs have the highest average tour length of $70 \mathrm{~km}$ (to-andfro), and the average tour length was the smallest for CRT (8 $\mathrm{km}$ ). The return trip length for $\mathrm{HCV}$ is higher than its attracted trip length because most of the HCVs, operating in the Sarojini Nagar market area were associated with the waste collection sector, and these vehicles are required to travel long distances to reach recycling and dumping sites located on the outskirts of Delhi. On the contrary, the average return trip length for autorickshaws was observed as shortest because after delivery in the market, such vehicles are again used to transit passengers from the market or nearby area to their destination.

It was observed that mini-LCVs (12) and LCVs (14) were having the highest number of service points in a trip at Sarojini Nagar market. Vehicles (two-wheelers and cycles) capable of carrying a small amount of cargo, also had significantly higher service points, ranging from 10 to 12 . For other types of vehicles, the average number of service points vary between 1 and 6. Data also reveals that HCVs provide services to a higher number of nearby places (average 15.8). Autorickshaws generally provide point-specific services. The findings of drivers' interviews related to average tour length, cargo weight, service points for different vehicle types in Sarojini Nagar Market are summarised in Table 1.

\section{Fuel type and emission standards}

Around $83 \%$ of the freight trips in Gothenburg were made with diesel-powered vehicles, and the share of bi-fuel (a combination of two fuels, that is, diesel and compressed natural gas [CNG], etc.), petrol and natural gas-powered trips is only $13 \%, 2 \%$ and $2 \%$, respectively. The scenario is entirely different for Delhi. Around $76 \%$ of the freight trips were made by vehicles running on $\mathrm{CNG}$, whereas the share of diesel, liquid petroleum gas and petrol-powered trips was only $6 \%, 7 \%$ and $11 \%$, respectively. The data show that the freight vehicles running in Gothenburg have a cleaner technology when compared with Delhi. Around 54\% of the total trips in the study zone of Gothenburg were made by vehicles having engines, meeting Euro-V and stringent emission norms. In comparison, vehicular emission standards are relaxed in India, when compared with European countries. Bharat Stage (BS)-IV emission norms 
TABLE 1: Summary of the freight delivery pattern based on modal split and marginal external costs in Delhi.

\begin{tabular}{|c|c|c|c|c|c|c|c|c|c|}
\hline \multirow[t]{2}{*}{ Vehicle type } & \multirow[t]{2}{*}{$\begin{array}{l}\text { Passenger car } \\
\text { unit equivalent }\end{array}$} & \multirow[t]{2}{*}{$\begin{array}{l}\text { Avg. tour length } \\
(\mathrm{km})\end{array}$} & \multirow[t]{2}{*}{$\begin{array}{l}\text { Avg. cargo } \\
\text { weight (kg) }\end{array}$} & \multirow{2}{*}{$\begin{array}{l}\text { Avg. services } \\
\text { points in SN } \\
\text { market }\end{array}$} & \multicolumn{2}{|c|}{$\begin{array}{c}\text { MECcongestion (₹/vkm, } \\
2020 \text { prices) } \\
\end{array}$} & \multirow{2}{*}{$\begin{array}{l}\text { MECaccidents } \\
\text { (₹/vkm, } \\
2020 \text { prices) }\end{array}$} & \multicolumn{2}{|c|}{$\begin{array}{l}\text { MECnoise (₹/vkm, } \\
2020 \text { prices) }\end{array}$} \\
\hline & & & & & Peak & Off peak & & Peak & Off peak \\
\hline Delivery van & 1 & 38.8 & 127.5 & 5.8 & 31.25 & 2.03 & 0.09 & 0.14 & 0.37 \\
\hline Two-wheeler & 0.5 & 18.3 & 21.3 & 10.0 & 15.61 & 1.00 & 0.05 & 0.07 & 0.19 \\
\hline Auto-rickshaw & 1 & 15.9 & 81.1 & 1.7 & 31.25 & 2.03 & 0.13 & 0.71 & 1.87 \\
\hline CRT & 1.5 & 8.0 & 128.0 & 2.0 & 46.85 & 3.04 & 0.17 & 0.00 & 0.00 \\
\hline $\mathrm{HCV}$ & 4.5 & 35 & 9454.0 & 3.5 & 140.59 & 9.14 & 0.18 & 15.99 & 42.16 \\
\hline LCV & 1.5 & 70 & 3533.0 & 14.7 & 46.85 & 3.04 & 0.09 & 2.55 & 6.72 \\
\hline Mini-LCV & 1 & 21 & 966.0 & 12.8 & 31.25 & 2.03 & 0.05 & 2.12 & 5.60 \\
\hline
\end{tabular}

CRT, cycle rickshaw trolley; HCV, heavy commercial vehicle; LCV, light commercial vehicle.

(equivalent to Euro-IV) were implemented nationwide in April 2017, and recently, BS-VI standards were brought inforce since April 2020 (DieselNet 2020). The share of freight vehicles in Delhi meeting BS-I, BS-II, BS-III and BS-IV norms was $7 \%, 12 \%, 36 \%$ and $45 \%$, respectively. In the case of Gothenburg, the share of freight vehicles meeting norms is Euro-II (3.8\%), Euro-III (7.3\%) Euro-IV (34.8\%), Euro-V $(48.8 \%)$, enhanced environmentally friendly vehicle $(4.7 \%)$ and Euro-VI (0.6\%).

The IIT Kanpur Comprehensive Study on Air Pollution and Green House Gases in Delhi (2016) states that vehicles contribute $20 \%$ to the city's PM-2.5 emission load (Kanpur 2016). It is also estimated that emissions from the transport sector increased by $40 \%$ in 2018 when compared with 2010 (Beig et al. 2020). Our data analysis reveals that $51 \%$ of freight trips in the study zone of Delhi were made with vehicles having age less than 5 years. Only 20\% of the trips were made by more than 10 years old vehicles. In order to control emissions from the transportation sector, National Green Tribunal (NGT), Principal Bench, New Delhi, in 2015 imposed a ban on all diesel vehicles older than 10 years and all petrol vehicles older than 15 years, plying in Delhi-NCR. Previously, only diesel vehicles that were over 15 years of age were banned in the region. However, it is clear from the results that the share of freight vehicle trips more than the age of 10 years is relatively less and not all of them were being operated on diesel. Banning such vehicles does not seem a promising option for reducing freight vehicle emissions.

\section{Freight delivery patterns (based on receivers' data)}

Based on random selection, data for freight deliveries were collected in the study zone at Gothenburg and Delhi. From the analysis, it was observed that only $27 \%$ of stores were part of any chain or franchise in Delhi; however, this share was high up to $46 \%$ for Gothenburg. It was found that the frequency of freight delivery trips is almost similar for both the study zones. More than half of the delivery trips are made on a weekly basis. The share of such trips in Gothenburg and Delhi was $56.6 \%$ and $58.3 \%$, respectively. About $23.7 \%$ of delivery trips in Gothenburg and $27.2 \%$ of delivery trips in Delhi were made on a daily basis. The share of bi-monthly and monthly delivery trips ranges between $7 \%$ and $12 \%$.
If we focus on the sector-specific contribution in FTA, it is observed that stores involved in the business related to HoReCa are attracting more daily delivery trips in both the study zones. Restaurants and Cafes in Gothenburg attract average 1.2 trips per day; however, the number of such trips in case of Sarojini Nagar Market is 1.7. It was also observed that food outlets in Delhi, having a relatively less floor area when compared with restaurants and cafes, are attracting more average delivery trips (2.3 trips/day). The number of service-related trips was high for Gothenburg, almost every store gets laundry, windows and carpet cleaning services on a bi-monthly basis, but a very few stores get laundry and other regular services in Sarojini Nagar Market. Around half of the deliveries in both zones were made by LCV/MiniLCV. Low-carrying capacity vehicles like cycle and twowheeler, etc., have a higher share of delivery trips to restaurants and food outlets than other stores.

For freight trip generation studies, linear regression models outperform constant trip rate models (Holguín-Veras \& Jaller 2014). The efficiency of a model depends on the type of classification of sectors: land use-based, activity-based, industrial classification, etc. The classification should be such that it leads to homogenous classes regarding the determinants and pattern of FTG activity (Lawson et al. 2012). The activitybased classification was used to categorise different stores, such as retail: clothing or footwear, hotel and restaurants, and food outlets, etc. In order to predict the number of daily trips for different stores, FTA models based on employment size (no. of employees working in the shop), gross floor area, type of store, that is, part of a chain or not, amount of cargo $(\mathrm{kg} /$ week) were explored. It was observed that for FTA models, cargo weight was not a significant variable in the case of Sarojini Nagar Market. However, the floor area was found significant for food outlets, footwear and electronics stores. In the case of Gothenburg, a good linear correlation was observed between attracted freight trips and floor area, cargo weight and employment size, ranging from 0.45 to 0.80 . For both the study zones, it is observed that the number of delivery trips does not depend on whether the commercial establishment is part of a chain or franchise.

Single-variable-based models gave higher precision in FTA predictions. The precision of area and employment-size-based FTA models for Sarojini Nagar market was found to be low. It was clear from the scatter plot of the data that there is not 
much variation in delivery trips because of change in floor area or employment size for such stores. However, it was observed that with an increase in floor area, the number of delivery trips increases up to an extent. However, relatively bigger size stores attract a lesser number of delivery trips than the small stores. It may be because of the availability of more storage area and the preference for consolidated deliveries. FTA models for different sectors are summarised in Table 2. The explanatory power of the model $\left(R^{2}\right)$ and t-statistics (two tail) with respect to the confidence interval of $95 \%$ are also provided.

From the FTA model summary in Table 2, it can be noted that with the exception of food outlets, all the coefficients for the area, employment size and delivery weight of cargo are positive for all the sectors. Hence, it can be concluded that with an increase in the value of these variables, the number of daily delivery trips would increase, whereas with the increase in floor area for food outlets in Delhi, the number of daily trips decreases. The number of delivery trips increases with the increase in employment per floor area for the electronics sector. This is also a proxy indicator of footfall and sales. Higher employment or floor area denotes that more employees are required per customer or sale.

\section{Externalities due to urban freight traffic in study zones}

In order to quantify the negative impacts of urban freight traffic in study zones at Gothenburg and Delhi, five types of externalities, that is, (1) congestion, (2) climate change, (3) accidents, (4) noise and (5) environmental emissions, were considered in our analysis.

In this study, the environmental externality covers the cost to the society because of freight vehicle emissions of four major pollutants, that is, hydrogen compounds (HCs), carbon monoxide $(\mathrm{CO})$, nitrogen oxides $\left(\mathrm{NO}_{x}\right)$ and particulate matter-2.5 microns (PM-2.5). The vehicular emission (gm/ $\mathrm{km}$ ) is the function of vehicle type, environmental class, fuel type and traffic condition (ARAI 2008; Hausberger 2014). Total vehicular emission depends on trip length, for which

TABLE 2: Freight trip attraction models for different business activities in Gothenburg and Delhi.

\begin{tabular}{|c|c|c|c|c|c|}
\hline S. No. & Sector & $\begin{array}{c}\text { Sample } \\
\text { size }\end{array}$ & FTA model $\uparrow$ & $R^{2}$ & $t$-stat \\
\hline \multicolumn{6}{|c|}{ Gothenburg } \\
\hline 1 & Retail & 33 & Trips $=0.131+0.006$ (area) & 0.40 & 4.50 \\
\hline 2 & Retail & 33 & Trips $=-0.199+0.298$ (employment) & 0.35 & 4.26 \\
\hline 3 & Retail & 28 & Trips $=0.367+0.002$ (cargo weight) & 0.29 & 3.28 \\
\hline 4 & $\begin{array}{l}\text { Restaurants/ } \\
\text { cafes }\end{array}$ & 10 & Trips $=-0.063+0.151$ (employment) & 0.55 & 3.69 \\
\hline 5 & $\begin{array}{l}\text { Restaurants/ } \\
\text { cafes }\end{array}$ & 5 & Trips $=0.261+0.003$ (cargo weight) & 0.84 & 4.00 \\
\hline \multicolumn{6}{|l|}{ Delhi } \\
\hline 1 & Food outlets & 6 & Trips $=4.539-0.097$ (area) & 0.91 & -5.43 \\
\hline 2 & $\begin{array}{l}\text { Footwear } \\
\text { (retail) }\end{array}$ & 10 & Trips $=[0.218+0.0032 \text { (area) }]^{2}$ & 0.70 & -4.32 \\
\hline 3 & Electronics & 8 & $\begin{array}{l}\text { Trips }=-0.254+9.88 \text { [employment/ } \\
\text { area] }\end{array}$ & 0.76 & 3.52 \\
\hline
\end{tabular}

$\dagger$, area in $\mathrm{m}^{2}$; employment in numbers; cargo weight in $\mathrm{kg}$.

FTA, freight trip attraction. data were collected through drivers' interviews. The estimated amount of pollutants generated because of freight trips in the study zones is summarised in Table 3.

It is somewhat difficult to compare the negative impacts of freight traffic in both zones because of marginal external cost (MEC) functions for various externalities depending on the country's economics. Because of the difference in traffic characteristics of both the cities and the unavailability of data, it was desirable to use the same marginal cost functions. Hence, MEC values, recommended by European Union (MOVE 2014) and updated to 2020 prices (Triami Media BV 2020), were used for Gothenburg, whereas MEC values were derived for freight vehicles in Delhi (Maibach et al. 2008; Sen et al. 2010). The approaches used for the derivation of MEC functions for Delhi were almost similar to the techniques used by MOVE (2014). However, it is to be noted that MEC functions for Delhi, like $\mathrm{MEC}_{\text {accidents' }^{\prime}}$ does not include risk elasticity and $\mathrm{MEC}_{\text {noise }}$ does not focus on health impacts. MEC $_{\text {congestion }}$ for Gothenburg is based on the aggregated approach of FORGE model, whereas it is based on the value of time approach for Delhi (Sen et al. 2010; MOVE 2014). The MEC values for Delhi (2020 prices) are presented in Table 1. Climate change externality in this study only accounts for $\mathrm{CO}_{2}$ emissions. The cost of $\mathrm{CO}_{2}$ as EUR $110 /$ ton for Sweden and EUR 70/ton for India was considered for calculations (Ministry of Finance 2020; Ricke et al. 2018).

Generally, CNG vehicles generate higher emissions of hydrocarbons and carbon monoxide when compared with diesel or petrol vehicles; however, emissions of particulate matter, nitrogen oxide and carbon dioxide are lower from CNG vehicles (Blanchard, Teil \& Chevreuil 2006; Lowell 2013). The results reveal that $\mathrm{CO}_{2}$ emissions generated by freight vehicles in Delhi were almost half of Gothenburg. However, emissions of hydrocarbons are much higher, which is more damaging to the climate than $\mathrm{CO}_{2}$ (EIA 2014). There is a difference in the characteristics of vehicles and fuel type used for both the cities. Although CNG is the fuel for most freight vehicular trips, relatively outdated technology (BS-I to IV) is in place for Indian vehicles. This is responsible for higher PM emissions. The concentration of $\mathrm{PM}_{2.5}$ in the air has reached an alarming level for Delhi, and the results of

TABLE 3: Comparison of emissions and external cost because of freight traffic in the study zone at Gothenburg and Delhi.

\begin{tabular}{lcc}
\hline Particulars & Gothenburg & Delhi \\
\hline Pollutants (ton/year) & & \\
$\mathrm{HC}$ & 0.10 & 1.14 \\
$\mathrm{CO}$ & 0.94 & 4.48 \\
$\mathrm{NO}_{\mathrm{x}}$ & 4.39 & 4.29 \\
$\mathrm{PM}_{2.5}$ & 0.08 & 0.58 \\
$\mathrm{CO}_{2}$ & 1052.07 & 461.67 \\
Externality (1000€, 2020) & & \\
Congestion & 1014.28 & 566.52 \\
Environmental emissions & 43.10 & 20.70 \\
Climate change & 119.95 & 32.32 \\
Noise & 66.51 & 5.20 \\
Accident & 15.35 & 44.79 \\
\hline
\end{tabular}


this study also show that emissions of $\mathrm{PM}_{2.5}$ from freight activities in Delhi are almost seven times when compared with Gothenburg, from the almost similar amount of freight activities (Beig et al. 2020).

A comparison of external cost for both the study zones is shown in Table 3. For conversion of Rupee into Euro, a conversion factor of 1 Euro $=85$ Rupees (2020 prices) is used. Social cost because of congestion, environmental emissions and noise are less in Delhi because the cost for health damage, time loss, injuries, fatalities, ecological damage, etc. is also less. Therefore, comparing the external cost values is not a realistic approach for the measurement of negative impacts because of the unequal scale of conversion of externality to monetary value. However, it is interesting to note that India as a low-income country, where the value of statistical life and damage cost of accidents is much lower when compared with high-income groups, external cost because of accidents is much higher than developed and high-income countries like Sweden (Miller 2000). This indicates that fatal crash rates of freight vehicles in urban areas are much higher in Delhi (Mohan et al. 2009) when compared with Gothenburg, and that is why MEC of accidents for freight vehicles is also high.

Results of the sectoral analysis for Gothenburg reveal that 3PLP is the dominant sector and contributes one-third to total external cost. HoReCa is the second-highest contributor. The share of express courier and post sector is lowest. At the same time, other sectors have almost equal impacts. The share of congestion externality is far higher than other externalities. The share of accident externality is lowest in total external cost, and 3PLP is the dominating sector under this category too. The 3PLP and the construction and maintenance sectors are more responsible than any other sector for noise-related external costs because of the use of big-size trucks and most of the fleet operations during peak hours.

\section{Conclusion}

With the case study of Gothenburg and Delhi, this article presents the urban freight scenario in commercial land use. The findings of the study will be helpful for further research studies on sustainable freight movement strategies. It is observed that most of the freight movement in both the study zones are with small-sized vehicles, and their share ranges between $75 \%$ and $92 \%$. The total externality due to freight traffic can be reduced with an improved load factor. A variety of vehicles, even passenger vehicles like autorickshaws, cycles and two-wheelers with a substantial share of $28 \%$, are used for freight movement in Delhi. In both the study zones, more than $50 \%$ of the deliveries are made weekly, and more than $90 \%$ of the delivery trips are running on conventional fuel. Almost $74 \%$ of freight vehicle drivers were regular visitors to Sarojini Nagar market, which implies the presence of an informally organised sector and the scope of better management by policy-based measures for sustainable urban freight.
Although $76 \%$ of freight trips in the study zone at Delhi were made by CNG vehicles, total PM emissions were manifolds in comparison with Gothenburg. The vehicles meeting BS-IV/Euro-IV and below emission norms generate a significantly higher amount of PM emissions than those meeting Euro- $\mathrm{V}$ and above emission norms (Crippa et al. 2016). Accident rates for freight vehicles in urban areas are much higher in Delhi when compared with Gothenburg.

The findings of this study indicate substantial dissimilarities in freight traffic characteristics and operations in Gothenburg and Delhi. City-specific research is needed before adopting sustainable urban freight measures to improve the transportation system's performance and reduce negative impacts. Furthermore, most of the variables used in FTA modelling in this study have shown relatively low predictability, and there is a scope for future research to identify more significant variables for higher accuracy FTA models.

\section{Acknowledgements}

S.D. would like to thank the Volvo Research and Education Foundation (VREF) for study visit grant as an exchange student in Gothenburg, Sweden. S.D. also acknowledge the guidance of Ivan Sanchez-Diaz, Associate Professor, Technology Management and Economics, Chalmers University of Technology, Gotheburg, Sweden, for development of freight trip attraction (FTA) models in this study.

\section{Competing interests}

The authors declare that they have no financial or personal relationships that may have inappropriately influenced them in writing this article.

\section{Authors' contributions}

S.D., K.R.R., G.T. and S.B. all made equal conceptual contributions that led to the development of this article. S.D., in particular, carried out the data collection and analysis, whilst K.R.R., G.T. and S.B. have reviewed and improved the article.

\section{Ethical considerations}

This article followed all ethical standards for research without direct contact with human or animal subjects.

\section{Funding information}

This research work did not receive any specific grant from funding agencies in the public, commercial or not-for-profit sectors.

\section{Data availability}

The data that support the findings of this study are available from the author, [S.D.], upon reasonable request. 


\section{Disclaimer}

The views and opinions expressed in this article are those of the authors and do not necessarily reflect the official policy or position of any affiliated agency of the authors.

\section{References}

ARAI, 2008, Emission factor development for Indian Vehicles, 4th rev., Automotive Research Association of India, Pune, India.

Amaya, J., Arellana, J. \& Delgado-Lindeman, M., 2020, 'Stakeholders perceptions to sustainable urban freight policies in emerging markets', Transportation Research Part A: Policy and Practice 132, 329-348. https://doi.org/10.1016/j.tra.2019.11.017

Anderson, S., Allen, J. \& Browne, M., 2005, 'Urban logistics-How can it meet policy makers' sustainability objectives?', Journal of Transport Geography 13(1), 71-81. https://doi.org/10.1016/j.jtrangeo.2004.11.002

Behrends, S., 2011, 'Urban Freight Transport Sustainability the Interaction of Urban Freight and Intermodal Transport', Ph.D. thesis, Chalmers University of Technology, Gothenburg.

Behrends, S., Lindholm, M. \& Woxenius, J., 2008, 'The impact of urban freight transport: A definition of sustainability from an actor's perspective', Transportation Planning and Technology 31(6), 693-713. https://doi.org/10.1080/03081060802493247

Beig, G., George, M.P., Sahu, S.K., Rathod, A., Singh, S., Dole, S. et al., 2020, 'Towards baseline air pollution under COVID-19: Implication for chronic health and policy research for Delhi, India', Current Science (00113891) 119(7), 1178-1184. https:// doi.org/10.18520/cs/v119/i7/1178-1184

Blanchard, M., Teil, M.J. \& Chevreuil, M., 2006, 'The seasonal fate of PCBs in ambient air and atmospheric deposition in northern France', Journal of Atmospheric Chemistry 53(2), 123-144. https://doi.org/10.1007/s10874-006-1321-z

Browne, M., Allen, J., Nemoto, T., Patier, D. \& Visser, J., 2012, 'Reducing social and environmental impacts of urban freight transport: A review of some major cities', Procedia-Social and Behavioral Sciences 39, 19-33. https://doi.org/10.1016/j. sbspro.2012.03.088

Browne, M., Piotrowska, M., Woodburn, A. \& Allen, J., 2007, Literature review WM9: Part I-Urban freight transport. Green Logistics Project, University of Westminster, London.

Census 2011, 2020, Delhi population 2011 - 2020, viewed 22 December 2020, from https://www.census2011.co.in/census/state/delhi.html.

Crippa, M., Janssens-Maenhout, G., Guizzardi, D. \& Galmarini, S., 2016, 'EU effect: Exporting emission standards for vehicles through the global market economy', Journal of Environmental Management 183(Part 3), 959-971. https://doi. org/10.1016/j.jenvman.2016.09.068

Dablanc, L., 2007, 'Goods transport in large European cities: Difficult to organize, difficult to modernize', Transportation Research Part A: Policy and Practice 41(3), 280-285. https://doi.org/10.1016/j.tra.2006.05.005

Dablanc, L., 2011, 'City distribution, a key element of the urban economy: Guidelines for practitioners,' in C. Macharis \& S. Melo (eds.), City distribution and urban freight transport: Multiples perspectives, pp. 13-36, Edward Elgar Publishing, Northampton.

De Oliveira, L.K., França, J.G.D.C.B., Nascimento, C.D.O.L., De Oliveira, I.K., Meira, L.H \& Rabay, L., 2021, 'Evaluating problems and measures for a sustainable urban freight transport in Brazilian historical cities', Sustainable Cities and Society 69 102806. https://doi.org/10.1016/j.scs.2021.102806

Delhi Vahan Sewa, 2015, Vehicle information of registered vehicles in Delhi, viewed 15 February 2015], from http://vahan.dl.nic.in.

DieselNet, 2020, Emission Standards, viewed 22 December 2020, from https:// dieselnet.com/standards/in/.

EIA, 2014, How much carbon dioxide is produced when different fuels are burned? U.S Energy Information Administration, viewed 12 January 2015, from http://www. eia.gov/tools/faqs/faq.cfm?id=73\&t=11.

Ewbank, H., Vieira, J.G.V., Fransoo, J. \& Ferreira, M.A., 2020, 'The impact of urban freight transport and mobility on transport externalities in the SPMR' Transportation Research Procedia 46, 101-108. https://doi.org/10.1016/j trpro.2020.03.169

Goel, R. \& Guttikunda, S.K., 2015, 'Evolution of on-road vehicle exhaust emissions in Delhi', Atmospheric Environment 105, 78-90. https://doi.org/10.1016/j.atmosenv.2015.01.045

Google Maps, 2015, Map of Inom Vallgraven, Sweden and Sarojini Nagar Market, Delhi, India, viewed 11 January 2020, from https://www.google.com/maps/.

Gupta, S., 2017, 'Role of non-motorized transport in distribution of goods in the metropolitan city of Delhi', Transportation Research Procedia 25, 978-984. https://doi.org/10.1016/j.trpro.2017.05.472

Hausberger, S., 2014, Update of Emission Factors for EURO 5 and EURO 6 vehicles for the HBEFA Version 3.2, Graz University of Technology, Graz, Austria.

Holguín-Veras, J. \& Jaller, M., 2014, 'Comprehensive Freight demand Data Collection Framework for Large Urban Areas,' in J. González-Feliu, F. Semet \& J.-L. Routhier (eds.), Sustainable Urban Logistics: Concepts, Methods and Information Systems. EcoProduction, pp. 91-112, Springer, Berlin, Heidelberg.

Holguín-Veras, J., Jaller, M., Sánchez-Díaz, I., Wojtowicz, J., Campbell, S., Levinson, H. et al., 2012, NCHRP Report 739/NCFRP Report 19: Freight trip generation and land use, Transportation Research Board of the National Academies, Washington, DC.

Kaczorowska, A., 2014, 'Urban freight transport and urban form', Seminar In: Chalmers University of Technology, October, 2014, Gothenburg, Sweden.
Kanpur, I.I.T., 2016, 'Comprehensive study on air pollution and green house gases (GHGs) in Delhi', Final Report-Air Pollution Component, Submitted to Department of Environment of Government of National Capital Territory of Delhi and Delhi Pollution Control Committee, Kanpur: IIT.

Karakikes, I. \& Nathanail, E., 2020, 'Using the Delphi method to evaluate the appropriateness of urban freight transport solutions', Smart Cities 3(4), 1428-1447. https://doi.org/10.3390/smartcities3040068

Kin, B., Verlinde, S. \& Macharis, C., 2017, 'Sustainable urban freight transport in megacities in emerging markets', Sustainable Cities and Society 32, 31-41. https:// doi.org/10.1016/j.scs.2017.03.011

Lawson, C.T., Holguín-Veras, J., Sánchez-Díaz, I., Jaller, M., Campbell, S. \& Powers, E.L., 2012, 'Estimated generation of freight trips based on land use', Transportation Research Record 2269(1), 65-72. https://doi.org/10.3141/2269-08

LET-Aria Technologies-Systems Consult, 2006, Mise en place d'une methodologie pour un bilan environnemental physique du transport de marchandises en ville, consommation, emissions, qualite de l'air, Co-edition ADEME, CERTU, Lyon.

Lindholm, M., 2012, Enabling sustainable development of urban freight from a local authority perspective, Chalmers University of Technology.

Lindholm, M. \& Behrends, S., 2012, 'Challenges in urban freight transport planning -A review in the Baltic Sea Region', Journal of Transport Geography 22, 129-136. https://doi.org/10.1016/j.jtrangeo.2012.01.001

Lowell, D., 2013, Comparison of modern CNG, Diesel and Diesel hybrid-electric transit buses: Efficiency \& environmental performance, MJ Bradley \& Associates, LLC. Report, Boston.

Macharis, C. \& Melo, S., 2011, 'Introduction - City distribution: challenges for cities and researchers', in Macharis, C. \& Melo, S. (eds), City distribution and urban and researchers', in Macharis, C. \& Melo, S. (eds),
freight. transport, Edward Elgar, Cheltenham, UK.

Maibach, M., Schreyer, C., Sutter, D., Van Essen, H.P., Boon, B.H., Smokers, R. et al., 2007, Handbook on estimation of external cost in the transport sector: Produced within the study Internalisation Measures and Policies for All external Cost of Transport (IMPACT) (No. 07.4288. 52), CE Delft, Delft.

Maibach, M., Schreyer, C., Sutter, D., Van Essen, H.P., Boon, B.H., Smokers, R. et al., 2008 , Handbook on estimation of external costs in the transport sector, Ce Delft, 336, CE Delft, Delft.

McCutcheon, D.M. \& Meredith, J.R., 1993, 'Conducting case study research in operations management', Journal of Operations Management 11(3), 239-256. https://doi.org/10.1016/0272-6963(93)90002-7

Meredith, J., 1998, 'Building operations management theory through case and field research', Journal of Operations Management 16(4), 441-454. https://doi. research', Journal of Operations Man
org/10.1016/S0272-6963(98)00023-0

Miller, T.R., 2000, 'Variations Between Countries in Values of Statistical Life', Journal of Transport Economics and Policy 34(2), 169-188.

Ministry of Finance, 2020, Sweden's carbon tax, viewed 22 December 2020, from https://www.government.se/government-policy/taxes-and-tariffs/swedenscarbon-tax/.

Mohan, D., Tsimhoni, O., Sivak, M. \& Flannagan, M.J., 2009, Road safety in India: Challenges and opportunities, University of Michigan, Ann Arbor, MI, Transportation Research Institute.

MOVE, D., 2014, Update of the handbook on external costs of transport, Report for the European Commission: DG MOVE. Ricardo-AEA/R/ ED57769. Issue no.1, RicardoEuropean Commi
AEA, London.

Nilanjana, D.B., Bolia, N.B., Tiwari, G. \& Holguin-Veras, J., 2017, Urban freight in Delhi: Characteristics and mobility restrictions, VREF Research Brief 8 (RB08-2017), Volvo Research and Educational Foundations (VREF).

Ogden, K.W., 1992, Urban goods movement: A guide to policy and planning, Ashgate Publishing Company, Aldershot, England.

Oskarbski, J. \& Kaszubowski, D., 2018, 'Applying a mesoscopic Transport Model to analyse the effects of urban freight regulatory measures on transport emissionsAn assessment', Sustainability 10(7), 2515. https://doi.org/10.3390/su10072515

Punte, S., Gota, S. \& Peng, Y., 2013, Sustainable urban freight in Asian cities, viewed 14 April 2015, from http://cleanairinitiative.org/portal/sites/default/files/ 14 April 2015, from http://clean
documents/hs_susturbfreight2.pdf.

Quak, H., 2011, 'Urban freight transport: the challenge of sustainability', in C. Macharis \& S. Melo (eds.), City Distribution and Urban Freight Transport: Multiple Perspectives, pp. 37-55, Edward Elgar Publishing Limited, Cheltenham, UK.

Ricke, K., Drouet, L., Caldeira, K. \& Tavoni, M., 2018, 'Country-level social cost of carbon', Nature Climate Change 8(10), 895-900. https://doi.org/10.1038/s41558018-0282-y

Sen, A.K., Tiwari, G. \& Upadhyay, V., 2010, 'Estimating marginal external costs of transport in Delhi', Transport Policy 17(1), 27-37. https://doi.org/10.1016/j. tranpol.2009.09.003

Sjöstedt, L., 2007, RE: Classic focus on city planning, 4th International Conference on City Logistics, Langkawi, Malaysia.

Statistics Sweden, 2014, Swedish Standard Industrial Classification (2007), viewed 12 October 2014, from http://www.scb.se/en.

Statistics Sweden, 2020, Population in the country, counties and municipalities on September 30, 2020 and population change in January-September 2020, 22 December 2020, from https://www.scb.se/en/finding-statistics/statistics-bysubject-area/population/population-composition/population-statistics/pong/ tables-and-graphs/quarterly-population-statistics--municipalities-counties-andthe-whole-country/quarter-13-2020/.

Taniguchi, E. \& Thompson, R.G. (eds.), 2018, City Logistics 3: Towards Sustainable and Liveable Cities, John Wiley \& Sons, London, UK.

Transmodal, M.D.S., 2012, DG MOVE European Commission: Study on urban freight transport, viewed 19 December 2020, from https://civitas.eu/content/2012ecstu dyonurbanfreighttransportpdf. 
Transport Styrelesn, 2014, Find information on another vehicle, viewed 20 September 2014, from https://fordonsfraga.transportstyrelsen.se.

Triami Media BV, 2020, Historic inflation India - CPI inflation, viewed 25 Decembe 2020, from https://www.inflation.eu/en/inflation-rates/india/historic-inflation/ cpi-inflation-india.aspx.

UC All Companies Ltd., 2014, Swedish Company Database, viewed 30 December 2014 from http://www.allabolag.se.
UN DESA, 2019, World urbanization prospects - The 2018 revision. United Nations Department of Economic and Social Affairs, New York, NY, viewed 19 December 2020, from https://population.un.org/wup/Publications/Files/ WUP2018-Report.pdf.

Voss, C., Tsikriktsis, N. \& Frohlich, M., 2002, 'Case research in operations management', International Journal of Operations \& Production Management 22(2), 195-291. 